\author{
Yasuhiro Matsumura* \\ Department of Internal Medicine, Akishima \\ Hospital, 1260 Nakagami-cho, Akishima-shi, \\ Tokyo196-0022, Japan \\ Dates: Received: 20 July, 2015; Accepted: 18 \\ August, 2015; Published: 20 August, 2015 \\ *Corresponding author: Dr, Yasuhiro Matsumura, \\ Department of Internal Medicine, Akishima Hospital, \\ 1260 Nakagami-cho, Akishima-shi, Tokyo,196-0022, \\ Japan, Tel: +81-42-546-3111, Fax: +81-42-545-5175 \\ E-mail: y-matsumura@aki-hp.jp \\ www.peertechz.com
}

ISSN: 2455-8141

Keywords: Antioxidant; Bronchial asthma; Long-chain n-3 polyunsaturated fatty acid (LCn3PUFA); Methyl donor; Probiotic; Vitamin D

\author{
Review Article
}

\section{Dietary or Supplementary Intake Modulates Inflammatory Response in Asthma}

\begin{abstract}
Summary
The importance of diet and supplement intake in the onset and development of asthma has been advocated recently, and it may be important in the prevention and management of bronchial asthma. Long-chain n-3 polyunsaturated fatty acids (LCn3PUFAs), vitamins (Vit), choline, and probiotics may be candidates to reduce medication use and provide some protection from risk. Experimental studies of diet in bronchial asthma have demonstrated modification of pulmonary function and the immune system through mechanisms involving antioxidant effect, T-helper (Th) 2 and Th17 inhibition, tolerogenic regulatory $\mathrm{T}$ cell $(\mathrm{Treg})$ function promotion, nuclear transcription factors and epigenetic regulation. Although studies in animal models have provided evidence of supportive effects of diet in asthma, there have been few longitudinal studies of dietary or supplement intake and asthma, and the available epidemiological data remain controversial and inconclusive.
\end{abstract}

\section{Introduction}

\section{Epidemiological study of asthma prevalence with diet}

The diet has shifted towards one with less fruit and vegetables that is high in fat, salt and sugar and low in fiber and antioxidants. These changes are one possible explanation for the increase in bronchial asthma [1].

Frequent consumption of hamburgers showed a dose-dependent association with asthma symptoms [2]. Increased intake of saturated fatty acids (SFAs), myristic and palmitic acid, and butter were shown to be related to the risk of asthma in children [3]. Epidemiological studies have examined the association between the intake of fish or LCn3PUFAs, including eicosapentaenoic acid (EPA) and docosahexaenoic acid (DHA), which are abundant in fish, and the risk of asthma [4-7]. LC $\omega 3$ PUFA intake was significantly inversely associated with the incidence of asthma [8-10], but whether this benefit persists as other factors come into play remains to be determined.

A meta-analysis found a significant association between low dietary intake of Vit A and Vit C and asthma [11]. However, several studies indicated that supplementation of vitamins, such as Vit A [12] and Vit E [11] [13], was not associated with decreased risk of asthma. The potential benefits and risks of vitamin supplements might be considered in special situations, such as marked deficiency of dietary antioxidants, poor access to dietary antioxidants, or high exposure to environmental oxidants [14]. In pregnancy, consumption of antioxidant-rich food is a key modifier of clinical asthma status [15]. Maternal Vit E intake during pregnancy was inversely associated with wheeze in the first two years of life [16].

Low serum Vit D levels were observed in children with asthma [17-19]. Vit D deficiency in pregnant women resulted in a higher prevalence of asthma and allergy in their offspring [20]. Cord serum 25-Hydroxyvitamin D level was inversely associated with the risk of transient early wheezing by the age of 5 years, but no association was found with asthma [21]. Recent published data demonstrated that Vit D3 did not reduce the rate of first treatment failure or exacerbation in adults with persistent asthma and Vit D insufficiency, suggesting that therapeutic Vit D3 supplementation in patients with symptomatic asthma was not useful [22].

Bacteria-host interactions may bring about beneficial changes in immune responses. Probiotics, defined as "live micro-organisms that, when administered in adequate amounts, confer a health benefit on the host", may affect asthmatic condition in children [23]. However, there have been a limited number of clinical studies on the therapeutic potential of probiotics in asthmatics [24,25].

\section{Dietary effects on pulmonary function in asthma}

A high-fat challenge increases airway inflammation and impairs bronchodilator recovery in asthma. The increase in circulating endotoxin concentration induced by a high-fat diet [26] may induce increased expression of toll-like receptor 4 (TLR4) in sputum cells, which results in airway inflammation [27]. Higher fat and lower fiber intake were associated with lower forced expiratory volume in one second (FEV1) and airway eosinophilia. Leptin levels were increased in asthmatics as compared with healthy controls [28].

Environmental oxidants and airway inflammatory cell-generated reactive oxygen influence asthma symptoms. Supplementation with antioxidants (Vit C and Vit E) ameliorated the decrease in lung function by ozone exposure in children with moderate to severe asthma [29]. $\alpha$-tocopherol acts as a defense against oxidant-induced membrane injury in human tissue in that it disrupts the chain reaction of lipid peroxidation [30], suggesting anti-inflammatory properties. Maternal plasma $\alpha$-tocopherol level during pregnancy 
was positively associated with post-bronchodilator FEV1 in the child at 5 years of age [31]. $\gamma$-tocopherol has inflammatory properties [32]. High human plasma $\gamma$-tocopherol levels relate to intake of soybean oil, which is higher in $\gamma$-tocopherol than other oils such as sunflower, safflower and olive oil [33-35]. An increased serum concentration of $\gamma$-tocopherol is associated with lower FEV1 or forced vital capacity (FVC) [36], and high dietary intake of $\gamma$-tocopherol may be associated with the increase in asthma patients in the United States [37].

It has been reported that lower Vit D levels resulted in higher rates of asthma, associated with impaired lung function and increased airway hyperresponsiveness (AHR) $[38,39]$. However, the effect of vitamin $\mathrm{D}$ as sole therapy for airway hyper-reactivity and airway inflammation is still not clear [40].

\section{Effects on inflammatory cells and cytokines}

Airway inflammation in asthma is heterogeneous and is characterized by activation of Th2 cells, Th17 cells, eosinophils and neutrophils. DHA reduced eosinophil infiltration into the lung and improved lung function in a methacholine challenge asthma model [41]. DHA affects several types of lung cells to reduce the airway inflammatory response to organic dust extract (ODE) challenge in bronchial epithelial cells via reduced interleukin (IL)6 and IL- 8 release [42] [43]. The fat- 1 transgenic mouse model has demonstrated that balancing the $\omega-6 / \omega-3$ ratio can protect against chronic inflammatory diseases, and displayed increased endogenous LCn3PUFA. When allergen-sensitized and aerosol-challenged, these animals had decreased airway inflammation with decreased leukocyte accumulation in bronchoalveolar lavage fluid and lung parenchyma [44]. The n3PUFA-derived lipid mediators, protectin D1 and resolvin E1 (RvE1; 5S, 12R, 18R-trihydroxyeicosapentaenoic acid), may act as potent resolution agonists in airway inflammation. Intraperitoneal administration of RvE E1 in mice was observed to decrease airway eosinophil and lymphocyte recruitment, a specific Th2 cytokine, IL13, ovalbumin-specific IgE, and AHR to inhaled methacholine [45]. RvE1 promoted the resolution of inflammatory airway responses in part by directly suppressing the production of IL-23 and IL-6, which promote the survival and differentiation of IL-17-producing $\mathrm{T}$ helper cells in the lung [46].

Oxidative stress is involved in activation of various inflammatory cells, such as mast cells, lymphocytes, eosinophils, and neutrophils. Asthmatic subjects with AHR, uncontrolled asthma or a severe asthma pattern have impaired antioxidant defenses and are susceptible to the damaging effects of oxidative stress [47]. Fat-soluble vitamins have multiple modulatory effects on immune cells and exert their effects through their antioxidant and anti-inflammatory properties [48].

All-trans retinoic acid (ATRA), the most biologically active metabolite of Vit A, attenuated airway inflammation by inhibiting Th2 and Th17 differentiation and/or functions in a mouse model of allergic airway inflammation [49]. Vit A inhibits Th 17 cells [49] [50] and promotes differentiation of Treg cells [51,52]. The protective effect of fenretinide against ovalbumin-induced airway hyperresponsiveness and inflammation in the lungs was illustrated by complete block of infiltration of inflammatory cells to the airways and markedly diminished goblet cell proliferation, even though IgE remained high [53]. High dietary Vit A can promote a Th2 bias, whereas Vit A deficiency (VAD) can produce a Th1 bias. High dietary Vit A enhanced and VAD diminished the development of experimental asthma in a mouse model, suggesting that excessive intake of Vit A may increase the risk or severity of asthma in industrialized countries [54].

The role of Vit D as an immunoregulatory agent has gained wide recognition in recent years. Vit D reduced human airway smooth muscle (ASM) expression of chemokines, including fractalkine and CX3C chemokine [55,56]. Vit D could affect epithelial growth and differentiation [57]. Vit D has effects on immune cells, including Th1 and Th2 responses, promotes Treg cells, inhibits the development of pathogenic effector Th17 cells, and regulates maturation of dendritic cells [58,59]. 1,25-dihydroxyvitamin D3 (1,25(OH)2 D3) potentiates the efficacy of immunotherapy, and the regulatory cytokines IL-10 and TGF-beta play a crucial role in the effector phase of this mouse model [60]. Impaired induction of IL-10 by GC in T cells from GC-R asthmatics can be reversed by Vit D3 and IL-10 [61].

Respiratory effects of probiotics in animal models have included attenuating allergic airway responses and protecting against respiratory pathogens. Oral treatment with probiotics reduces allergic symptoms in ovalbumin-sensitized mice [62]. Perinatal Lactobacillus rhamnosus GG (LGG) supplementation has beneficial effects on the development of allergic asthma in offspring [63]. Oral treatment with LGG prior to sensitization attenuated airway inflammation and hyperreactivity in a mouse model of allergic airway inflammation [64]. Oral treatment with live Lactobacillus reuteri (L. reuteri) significantly attenuated influx of eosinophils into the airway lumen and parenchyma and reduced the levels of tumor necrosis factor, monocyte chemoattractant protein-1, IL-5, and IL-13 in bronchoalveolar lavage fluid of antigen-challenged animals [65]. Oral administration of L. gasseri attenuated allergen-induced airway inflammation and IL-17 pro-inflammatory immune response in a mouse model of allergic asthma [66]. LGG [67] [68], L. reuteri [69] and Bifidobacterium longum (B. longum) $[70,71]$ have been reported to attenuate allergic airway response by induction of Treg cells. These protective effects may be associated with microbe-induced changes in dendritic cell phenotype and function [72]. Dietary fermentable fiber and short-chain fatty acids (SCFAs), which are metabolized by the gut microbiota, can shape the immunological environment in the lung and influence the severity of allergic inflammation [73].

\section{Effects on intracellular inflammatory pathways and nuclear factors}

Excessive fat intake stimulates NF- $\kappa$ B and increases IL- 6 and $\mathrm{CRP}$, suggesting that a high-fat diet augments neutrophilic airway inflammation [27]. High dietary intake of saturated fat can activate the innate immune response, as saturated fatty acids can directly activate TLR4, which also leads to an NF- $\kappa B$-driven inflammatory cascade [74]. LCn3PUFAs are known to decrease inflammation by inhibiting arachidonic acid (AA) metabolism to eicosanoids, decreasing the production of pro-inflammatory cytokines and reducing immune cell function. A recent study revealed that $\omega-3$ fatty acids are involved in altered pro- and anti-inflammatory transcription factor activation. EPA and DHA might suppress inflammatory signaling via NF- $\kappa B$ and 
G-protein-coupled receptor 120 (GPR120), which initiates an antiinflammatory signaling cascade that inhibits signaling leading to NF$\kappa \mathrm{B}$ activation [75].

Low antioxidant intake impairs the host's ability to scavenge reactive oxygen species (ROC), thereby promoting an NF- $\mathrm{kB}$ mediated innate immune response, resulting in oxidative damage. Vit $\mathrm{E}$ has been shown to inhibit NF- $\mathrm{\kappa B}$ pathways. Vit E blocks binding of transcription factors to two important IL-4 promoter binding sites for NF- $\mathrm{kB}$ and AP-1, and interferes with promoter activity upon T cell activation [76]. Vit E prevented the suppression of nuclear factor (erythroid-derived-2)-like 2 (NRF2), which has been found to be a critical regulator of antioxidant and defense genes with antioxidant response elements in their promoters [77].

Zinc is known to modulate the immune system via the NF- $\kappa B$ pathway [78]. Zinc supplementation alters NF- $\kappa B$ activity via the alteration of A20 activity [79].

\section{Effects of diet on epigenetic regulation in bronchial asthma}

The influence of epigenetic variations on asthma pathophysiology has been discussed [80]. Epigenetic mechanisms, including DNA methylation [81,82], histone modifications, and noncoding RNAs, can affect gene transcription [83].

Recent evidence has shown that dynamic changes in DNA methylation can provide a possible mechanistic explanation for the link between exposure to allergens and airway hyperresponsiveness $[84,85]$. Changes in DNA methylation can affect asthma pathogenesis [86] by modulating the expression of disease-related genes [87]. Altered DNA methylation in the STAT5A gene, which might be intrinsic to asthma phenotypes, could have implications in allergic airway disease [81]. Methyl donors for DNA methylation are mostly derived from the diet, and a diet high in methyl donors, such as folic acid, Vit B12, and L-methionine, could contribute to asthma risk. Methyl donor exposure promoted the development of allergy in an animal model [88]. Excessive methylated Runt-related transcription factor 3 (Runx3), a gene known to negatively regulate allergic airway disease, has been advocated as one of the mechanisms [89].

Data on folic acid supplementation in humans and associated allergic disease have been mixed. While some studies found that prenatal folic acid supplementation was associated with more asthma, wheeze, and other respiratory problems in early childhood $[90,91]$, others did not find an association [92-94]. Whether folate status affects disease severity or control in people who already suffer from asthma is also unclear [95]. Given its protective effects against neural tube and cardiac defects, there is no reason to alter current recommendations for folic acid supplementation during conception and pregnancy based on the findings on folate in asthma [96]. There is insufficient evidence to recommend the use of methyl donors for the prevention or treatment of asthma.

Choline can act as a methyl donor through its intermediate oxidation to betaine, which can subsequently convert homocysteine to methionine. A greater intake of choline and betaine from the diet was independently associated with a reduction in inflammation [97].
In a mouse model, choline might attenuate allergic inflammation in airway inflammation by reducing oxidative stress, possibly by modulating the redox status of the cell $[98,99]$.

Differences in histone acetylation and methylation have been linked to either a difference in enzyme activity or chromatin binding in a disease state. 1,25( $\mathrm{OH}) 2 \mathrm{D} 3$ upregulated histone $\mathrm{H} 4$ acetylation and participated in other chromatin remodeling events important to the expression of pro inflammatory genes [100]. Acinetobacter lwoffii F78 bacterium was able to prevent the development of an asthma phenotype via histone modification at the IFNG promoter [101]. Food allergens themselves have been found to be susceptible to epigenetic regulation. The promoter of the peanut allergen Ara h 3 underwent changes in histone acetylation, influencing its gene expression in early- and late-maturation embryos [102].

\section{Conclusion}

In June 2015, the U.S. Food and Drug Administration (FDA) took steps to remove artificial trans fats in processed foods, which increase the risk of raised LDL-cholesterol level, which is involved in the development of heart disease. Considering that the shift in nutrition to higher intake of processed food and reduced intake of vegetables may associate with the prevalence and symptoms of asthma, similar intervention to that for SFAs or announcement that conventional foods that contain antioxidants, probiotics, choline, and $\omega-3$ fatty acids may reduce the risk of asthma could contribute to reduction of asthma prevalence and symptoms. To do so, further high quality research on asthma and diet is required.

\section{References}

1. Scott HA, Jensen ME, Wood LG (2014) Dietary interventions in asthma. Curr Pharm Des 20: 1003-1010.

2. Wickens K, Barry D, Friezema A, Rhodius R, Bone N, et al. (2005) Fast foods - are they a risk factor for asthma? Allergy 60: 1537-1541.

3. Rodríguez-Rodríguez E, Perea JM, Jiménez Al, Rodríguez-Rodríguez P, López-Sobaler AM, et al. (2010) Fat intake and asthma in Spanish schoolchildren. Eur J Clin Nutr 64: 1065-1071.

4. Troisi RJ, Willett WC, Weiss ST, Trichopoulos D, Rosner B, et al. (1995) A prospective study of diet and adult-onset asthma. Am J Respir Crit Care Med 151: 1401-1408.

5. Kull I, Bergström A, Lilja G, Pershagen G, Wickman M (2006) Fish consumption during the first year of life and development of allergic diseases during childhood. Allergy 61: 1009-1015.

6. Chipps BE, Zeiger RS, Borish L, Wenzel SE, Yegin A, et al. (2012) Key findings and clinical implications from The Epidemiology and Natural History of Asthma: Outcomes and Treatment Regimens (TENOR) study. J Allergy Clin Immunol 130: 332-342.

7. Lumia M, Luukkainen P, Kaila M, Tapanainen H, Takkinen HM, et al. (2012) Maternal dietary fat and fatty acid intake during lactation and the risk of asthma in the offspring. Acta Paediatr 101: e337-343.

8. Li J, Xun P, Zamora D, Sood A, Liu K, et al. (2013) Intakes of long-chain omega-3 ( $\mathrm{n}-3$ ) PUFAs and fish in relation to incidence of asthma among American young adults: the CARDIA study. Am J Clin Nutr 97: 173-178.

9. Calder PC, Kremmyda LS, Vlachava M, Noakes PS, Miles EA (2010) Is there a role for fatty acids in early life programming of the immune system? Proc Nutr Soc 69: 373-380. 
10. Yang $\mathrm{H}$, Xun $\mathrm{P}, \mathrm{He} \mathrm{K}$ (2013) Fish and fish oil intake in relation to risk of asthma: a systematic review and meta-analysis. PLoS One 8: e80048.

11. Allen S, Britton JR, Leonardi-Bee JA (2009) Association between antioxidant vitamins and asthma outcome measures: systematic review and metaanalysis. Thorax 64: 610-619.

12. Checkley W, West KP Jr, Wise RA, Wu L, LeClerq SC, et al. (2011) Supplementation with vitamin A early in life and subsequent risk of asthma. Eur Respir J 38: 1310-1319.

13. Pearson PJ, Lewis SA, Britton J, Fogarty A (2004) Vitamin E supplements in asthma: a parallel group randomised placebo controlled trial. Thorax 59: 652 656.

14. Moreno-Macias H, Romieu I (2014) Effects of antioxidant supplements and nutrients on patients with asthma and allergies. J Allergy Clin Immunol 133 1237-1244.

15. Grieger JA, Wood LG, Clifton VL (2014) Antioxidant-rich dietary intervention for improving asthma control in pregnancies complicated by asthma: study protocol for a randomized controlled trial. Trials 15: 108.

16. Martindale S, McNeill G, Devereux G, Campbell D, Russell G, et al. (2005) Antioxidant intake in pregnancy in relation to wheeze and eczema in the firs two years of life. Am J Respir Crit Care Med 171: 121-128.

17. Brehm JM, Celedón JC, Soto-Quiros ME, Avila L, Hunninghake GM, et al (2009) Serum vitamin D levels and markers of severity of childhood asthma in Costa Rica. Am J Respir Crit Care Med 179: 765-771.

18. Majak P, Olszowiec-Chlebna M, Smejda K, Stelmach I (2011) Vitamin D supplementation in children may prevent asthma exacerbation triggered by acute respiratory infection. J Allergy Clin Immunol 127: 1294-1296.

19. Bener A, Ehlayel MS, Tulic MK, Hamid Q (2012) Vitamin D deficiency as a strong predictor of asthma in children. Int Arch Allergy Immunol 157: 168-175.

20. Litonjua AA, Weiss ST (2007) Is vitamin D deficiency to blame for the asthma epidemic? J Allergy Clin Immunol 120: 1031-1035.

21. Baïz N, Dargent-Molina P, Wark JD, Souberbielle JC, Annesi-Maesano (2014) Cord serum 25-hydroxyvitamin D and risk of early childhood transient wheezing and atopic dermatitis. J Allergy Clin Immunol 133: 147-153.

22. Castro M, King TS, Kunselman SJ, Cabana MD, Denlinger L, et al. (2014) Effect of vitamin D3 on asthma treatment failures in adults with symptomatic asthma and lower vitamin D levels: the VIDA randomized clinical trial. JAMA 311: 2083-2091.

23. Miraglia Del Giudice M, Maiello N, Decimo F, Fusco N, D' Agostino B, et al. (2012) Airways allergic inflammation and L. reuterii treatment in asthmatic children. J Biol Regul Homeost Agents 26: S35-40.

24. Vliagoftis H, Kouranos VD, Betsi GI, Falagas ME (2008) Probiotics for the treatment of allergic rhinitis and asthma: systematic review of randomized controlled trials. Ann Allergy Asthma Immunol 101: 570-579.

25. Reid G (2005) The importance of guidelines in the development and application of probiotics. Curr Pharm Des 11: 11-16.

26. Pendyala S, Walker JM, Holt PR (2012) A high-fat diet is associated with endotoxemia that originates from the gut. Gastroenterology 142: 1100-1101.

27. Wood LG, Garg ML, Gibson PG (2011) A high-fat challenge increases airway inflammation and impairs bronchodilator recovery in asthma. J Allergy Clin Immunol 127: 1133-1140

28. Berthon BS, Macdonald-Wicks LK, Gibson PG, Wood LG (2013) Investigation of the association between dietary intake, disease severity and airway inflammation in asthma. Respirology 18: 447-454.

29. Romieu I, Sienra-Monge JJ, Ramírez-Aguilar M, Téllez-Rojo MM, MorenoMacías $\mathrm{H}$, et al. (2002) Antioxidant supplementation and lung functions among children with asthma exposed to high levels of air pollutants. Am J Respir Crit Care Med 166: 703-709.
30. Lobo V, Patil A, Phatak A, Chandra N (2010) Free radicals, antioxidants and functional foods: Impact on human health. Pharmacogn Rev 4: 118-126.

31. Devereux G, Turner SW, Craig LC, McNeill G, Martindale S, et al. (2006) Low maternal vitamin $E$ intake during pregnancy is associated with asthma in 5-year-old children. Am J Respir Crit Care Med 174: 499-507.

32. Cook-Mills JM (2013) Isoforms of vitamin E differentially regulate PKC ? and inflammation: a review. J Clin Cell Immunol 4: pii: 1000137.

33. Jiang Q, Christen S, Shigenaga MK, Ames BN (2001) Gamma-tocopherol, the major form of vitamin $\mathrm{E}$ in the US diet, deserves more attention. Am J Clin Nutr 74: 714-722

34. Talegawkar SA, Johnson EJ, Carithers T, Taylor HA Jr, Bogle ML, et al. (2007) Total alpha-tocopherol intakes are associated with serum alphatocopherol concentrations in African American adults. J Nutr 137: 2297-2303.

35. Berdnikovs S, Abdala-Valencia H, McCary C, Somand M, Cole R, et al. (2009) Isoforms of vitamin $E$ have opposing immunoregulatory functions during inflammation by regulating leukocyte recruitment. J Immunol 182: 4395-4405.

36. Marchese ME, Kumar R, Colangelo LA, Avila PC, Jacobs DR Jr, et al. (2014) The vitamin E isoforms ?-tocopherol and ?-tocopherol have opposite associations with spirometric parameters: the CARDIA study. Respir Res 15: 31.

37. Cook-Mills JM, Avila PC (2014) Vitamin E and D regulation of allergic asthma immunopathogenesis. Int Immunopharmacol 23: 364-372.

38. Camargo CA Jr, Rifas-Shiman SL, Litonjua AA, Rich-Edwards JW, Weiss ST, et al. (2007) Maternal intake of vitamin D during pregnancy and risk of recurrent wheeze in children at 3 y of age. Am J Clin Nutr 85: 788-795.

39. Alyasin S, Momen T, Kashef S, Alipour A, Amin R (2011) The relationship between serum 25 hydroxy vitamin $D$ levels and asthma in children. Allergy Asthma Immunol Res 3: 251-255.

40. Bar Yoseph R, Livnat G, Schnapp Z, Hakim F, Dabbah H, et al. (2015) The effect of vitamin $D$ on airway reactivity and inflammation in asthmatic children: A double-blind placebo-controlled trial. Pediatr Pulmonol 50: 747-753.

41. Yokoyama A, Hamazaki T, Ohshita A, Kohno N, Sakai K, et al. (2000) Effect of aerosolized docosahexaenoic acid in a mouse model of atopic asthma. Int Arch Allergy Immunol 123: 327-332.

42. Nordgren TM, Heires AJ, Wyatt TA, Poole JA, LeVan TD, et al. (2013) Maresin-1 reduces the pro-inflammatory response of bronchial epithelial cells to organic dust. Respir Res 14: 51

43. Nordgren TM, Friemel TD, Heires AJ, Poole JA, Wyatt TA, et al. (2014) The omega-3 fatty acid docosahexaenoic acid attenuates organic dust-induced airway inflammation. Nutrients 6: 5434-5452.

44. Bilal S, Haworth O, Wu L, Weylandt KH, Levy BD, et al. (2011) Fat-1 transgenic mice with elevated omega-3 fatty acids are protected from allergic airway responses. Biochim Biophys Acta 1812: 1164-1169.

45. Aoki H, Hisada T, Ishizuka T, Utsugi M, Kawata T, et al. (2008) Resolvin E1 dampens airway inflammation and hyperresponsiveness in a murine model of asthma. Biochem Biophys Res Commun 367: 509-515.

46. Haworth O, Cernadas M, Yang R, Serhan CN, Levy BD (2008) Resolvin E1 regulates interleukin 23 , interferon-gamma and lipoxin A4 to promote the resolution of allergic airway inflammation. Nat Immunol 9: 873-879.

47. Wood LG, Gibson PG (2010) Reduced circulating antioxidant defences are associated with airway hyper-responsiveness, poor control and severe disease pattern in asthma. Br J Nutr 103: 735-741.

48. Mora JR, Iwata M, von Andrian UH (2008) Vitamin effects on the immune system: vitamins A and D take centre stage. Nat Rev Immunol 8: 685-698.

49. Wu J, Zhang Y, Liu Q, Zhong W, Xia Z (2013) All-trans retinoic acid attenuates airway inflammation by inhibiting Th2 and Th17 response in experimental allergic asthma. BMC Immunol 14: 28. 
50. Mucida D, Park Y, Kim G, Turovskaya O, Scott I, et al. (2007) Reciprocal $\mathrm{TH} 17$ and regulatory $\mathrm{T}$ cell differentiation mediated by retinoic acid. Science 317: $256-260$.

51. Benson MJ, Pino-Lagos K, Rosemblatt M, Noelle RJ (2007) All-trans retinoic acid mediates enhanced $T$ reg cell growth, differentiation, and gut homing in the face of high levels of co-stimulation. J Exp Med 204: 1765-1774.

52. Sun CM, Hall JA, Blank RB, Bouladoux N, Oukka M, et al. (2007) Small intestine lamina propria dendritic cells promote de novo generation of Foxp3 T reg cells via retinoic acid. J Exp Med 204:1775-1785.

53. Kanagaratham C, Kalivodová A, Najdekr L, Friedecký D, Adam T, et al. (2014) Fenretinide prevents inflammation and airway hyperresponsiveness in a mouse model of allergic asthma. Am J Respir Cell Mol Biol 51: 783-792.

54. Schuster GU, Kenyon NJ, Stephensen CB (2008) Vitamin A deficiency decreases and high dietary vitamin $A$ increases disease severity in the mouse model of asthma. J Immunol 180: 1834-1842.

55. Sukkar MB, Issa R, Xie S, Oltmanns U, Newton R, et al. (2004) Fractalkine/ CX3CL1 production by human airway smooth muscle cells: induction by IFNgamma and TNF-alpha and regulation by TGF-beta and corticosteroids. Am J Physiol Lung Cell Mol Physiol 287: L1230-1240.

56. Banerjee A, Damera G, Bhandare R, Gu S, Lopez-Boado Y, et al. (2008) Vitamin $D$ and glucocorticoids differentially modulate chemokine expression in human airway smooth muscle cells. Br J Pharmacol 155: 84-92.

57. Brockman-Schneider RA, Pickles RJ, Gern JE (2014) Effects of vitamin D on airway epithelial cell morphology and rhinovirus replication. PLoS One 9 e86755.

58. Wjst M (2006) The vitamin D slant on allergy. Pediatr Allergy Immunol 17: 477-483.

59. Paul G, Brehm JM, Alcorn JF, Holguín F, Aujla SJ, et al. (2012) Vitamin D and asthma. Am J Respir Crit Care Med 185: 124-132.

60. Taher YA, van Esch BC, Hofman GA, Henricks PA, van Oosterhout AJ (2008) 1alpha,25-dihydroxyvitamin D3 potentiates the beneficial effects of allergen immunotherapy in a mouse model of allergic asthma: role for IL-10 and TGFbeta. J Immunol 180: 5211-5221.

61. Xystrakis E, Kusumakar S, Boswell S, Peek E, Urry Z, et al. (2006) Reversing the defective induction of IL-10-secreting regulatory $T$ cells in glucocorticoidresistant asthma patients. J Clin Invest 116: 146-155

62. Hougee S, Vriesema AJ, Wijering SC, Knippels LM, Folkerts G, et al. (2010) Oral treatment with probiotics reduces allergic symptoms in ovalbuminsensitized mice: a bacterial strain comparative study. Int Arch Allergy Immunol 151: 107-117.

63. Blümer N, Sel S, Virna S, Patrascan CC, Zimmermann S, et al. (2007) Perinatal maternal application of Lactobacillus rhamnosus GG suppresses allergic airway inflammation in mouse offspring. Clin Exp Allergy 37: 348-357.

64. Yu J, Jang SO, Kim BJ, Song YH, Kwon JW, et al. (2010) The effects of Lactobacillus rhamnosus on the prevention of asthma in a murine model. Allergy Asthma Immunol Res 2: 199-205.

65. Forsythe $\mathrm{P}$, Inman MD, Bienenstock J (2007) Oral treatment with live Lactobacillus reuteri inhibits the allergic airway response in mice. Am J Respir Crit Care Med 175: 561-569.

66. Jan RL, Yeh KC, Hsieh MH, Lin YL, Kao HF, et al. (2012) Lactobacillus gasseri suppresses Th17 pro-inflammatory response and attenuates allergen-induced airway inflammation in a mouse model of allergic asthma Br J Nutr 108: 130-139.

67. Feleszko W, Jaworska J, Rha RD, Steinhausen S, Avagyan A, et al. (2007) Probiotic-induced suppression of allergic sensitization and airway inflammation is associated with an increase of $T$ regulatory-dependent mechanisms in a murine model of asthma. Clin Exp Allergy 37: 498-505.

68. Jang SO, Kim HJ, Kim YJ, Kang MJ, Kwon JW, et al. (2012) Asthma prevention by Lactobacillus rhamnosus in a mouse model is associated with CD4(+)CD25(+)Foxp3(+) T cells. Allergy Asthma Immunol Res 4: 150-156.
69. Karimi K, Inman MD, Bienenstock J, Forsythe P (2009) Lactobacillus reuteriinduced regulatory $\mathrm{T}$ cells protect against an allergic airway response in mice. Am J Respir Crit Care Med 179: 186-193.

70. Lyons A, O'Mahony D, O'Brien F, MacSharry J, Sheil B, et al. (2010) Bacteria strain-specific induction of Foxp3+ T regulatory cells is protective in murine allergy models. Clin Exp Allergy 40: 811-819.

71. MacSharry J, O'Mahony C, Shalaby KH, Sheil B, Karmouty-Quintana H, et al (2012) Immunomodulatory effects of feeding with Bifidobacterium longum on allergen-induced lung inflammation in the mouse. Pulm Pharmacol Ther 25: 325-334.

72. Forsythe $P$ (2014) Probiotics and lung immune responses. Ann Am Thorac Soc 11: S33-37.

73. Trompette A, Gollwitzer ES, Yadava K, Sichelstiel AK, Sprenger N, et al. (2014) Gut microbiota metabolism of dietary fiber influences allergic airway disease and hematopoiesis. Nat Med 20: 159-166.

74. Wood LG, Gibson PG (2009) Dietary factors lead to innate immune activation in asthma. Pharmacol Ther 123: 37-53.

75. Calder PC (2015) Marine omega-3 fatty acids and inflammatory processes: Effects, mechanisms and clinical relevance. Biochim Biophys Acta 1851: 469-484.

76. Li-Weber M, Giaisi M, Treiber MK, Krammer PH (2002) Vitamin E inhibits IL-4 gene expression in peripheral blood T cells. Eur J Immunol 32: 2401-2408.

77. Dworski R, Han W, Blackwell TS, Hoskins A, Freeman ML (2011) Vitamin E prevents NRF2 suppression by allergens in asthmatic alveolar macrophages in vivo. Free Radic Biol Med 51: 516-521.

78. Bao S, Liu MJ, Lee B, Besecker B, Lai JP, et al. (2010) Zinc modulates the innate immune response in vivo to polymicrobial sepsis through regulation of NF-kappaB. Am J Physiol Lung Cell Mol Physiol 298: L744-754.

79. Morgan Cl, Ledford JR, Zhou P, Page K (2011) Zinc supplementation alters airway inflammation and airway hyperresponsiveness to a common allergen. J Inflamm (Lond) 8: 36.

80. Salam MT (2014) Asthma epigenetics. Adv Exp Med Biol 795: 183-199.

81. Stefanowicz D, Hackett TL, Garmaroudi FS, Günther OP, Neumann S, et al. (2012) DNA methylation profiles of airway epithelial cells and PBMCs from healthy, atopic and asthmatic children. PLoS One 7: e44213.

82. Han YY, Blatter J, Brehm JM, Forno E, Litonjua AA, et al. (2013) Diet and asthma: vitamins and methyl donors. Lancet Respir Med 1: 813-822.

83. Lovinsky-Desir S, Miller RL (2012) Epigenetics, asthma, and allergic diseases: a review of the latest advancements. Curr Allergy Asthma Rep 12: 211-220.

84. Shang Y, Das S, Rabold R, Sham JS, Mitzner W, et al. (2013) Epigenetic alterations by DNA methylation in house dust mite-induced airway hyperresponsiveness. Am J Respir Cell Mol Biol 49: 279-287.

85. Cheng RY, Shang Y, Limjunyawong N, Dao T, Das S, et al. (2014) Alterations of the lung methylome in allergic airway hyper-responsiveness. Environ Mol Mutagen 55: 244-255

86. Sharma S, Litonjua A (2014) Asthma, allergy, and responses to methyl donor supplements and nutrients. J Allergy Clin Immunol 133: 1246-1254.

87. Michel S, Busato F, Genuneit J, Pekkanen J, Dalphin JC, et al. (2013) Farm exposure and time trends in early childhood may influence DNA methylation in genes related to asthma and allergy. Allergy 68: 355-364.

88. Robison R, Kumar R (2010) The effect of prenatal and postnatal dietary exposures on childhood development of atopic disease. Curr Opin Allergy Clin Immunol 10: 139-144.

89. Hollingsworth JW, Maruoka S, Boon K, Garantziotis S, Li Z, et al. (2008) In utero supplementation with methyl donors enhances allergic airway disease in mice. J Clin Invest 18: 3462-3469.

90. Whitrow MJ, Moore VM, Rumbold AR, Davies MJ (2009) Effect of 
supplemental folic acid in pregnancy on childhood asthma: a prospective birth cohort study. Am J Epidemiol 170: 1486-1493.

91. Håberg SE, London SJ, Nafstad P, Nilsen RM, Ueland PM, et al. (2011) Maternal folate levels in pregnancy and asthma in children at age 3 years. $J$ Allergy Clin Immunol 127: 262-264.

92. Matsui EC, Matsui W (2009) Higher serum folate levels are associated with a lower risk of atopy and wheeze. J Allergy Clin Immunol 123: 1253-1259.

93. Magdelijns FJ, Mommers M, Penders J, Smits L, Thijs C (2011) Folic acid use in pregnancy and the development of atopy, asthma, and lung function in childhood. Pediatrics 128: e135-144.

94. Brown SB, Reeves KW, Bertone-Johnson ER (2014) Maternal folate exposure in pregnancy and childhood asthma and allergy: a systematic review. Nutr Rev 72: 55-64.

95. Lin JH, Matsui W, Aloe C, Peng RD, Diette GB, et al. (2013) Relationships between folate and inflammatory features of asthma. J Allergy Clin Immunol 131: 918-920.

96. Blatter J, Han YY, Forno E, Brehm J, Bodnar L, et al. (2013) Folate and asthma. Am J Respir Crit Care Med 188: 12-17.
97. Detopoulou P, Panagiotakos DB, Antonopoulou S, Pitsavos C, Stefanadis C (2008) Dietary choline and betaine intakes in relation to concentrations of inflammatory markers in healthy adults: the ATTICA study. Am J Clin Nutr 87: 424-430.

98. Mehta AK, Arora N, Gaur SN, Singh BP (2009) Choline supplementation reduces oxidative stress in mouse model of allergic airway disease. Eur $\mathrm{J}$ Clin Invest 39: 934-941.

99. Mehta AK, Singh BP, Arora N, Gaur SN (2010) Choline attenuates immune inflammation and suppresses oxidative stress in patients with asthma. Immunobiology 215: 527-534.

100. Sundar IK, Rahman I (2011) Vitamin D and susceptibility of chronic lung diseases: role of epigenetics. Front Pharmacol 2: 50.

101. Brand S, Teich R, Dicke T, Harb H, Yildirim AÖ, et al. (2011) Epigenetic regulation in murine offspring as a novel mechanism for transmaternal asthma protection induced by microbes. J Allergy Clin Immunol 128: 618625 .

102. Fu G, Zhong Y, Li C, Li Y, Lin X, et al. (2010) Epigenetic regulation of peanut allergen gene Ara h 3 in developing embryos. Planta 231: 1049-1060.

Copyright: () 2015 Matsumura Y. This is an open-access article distributed under the terms of the Creative Commons Attribution License, which permits unrestricted use, distribution, and reproduction in any medium, provided the original author and source are credited. 